\title{
Influence of pasture allowance on the composition and cheese-yielding potential of milk.
}

\author{
M.J. AULDIST ${ }^{1}$, W. VAN DER POEL ${ }^{1}$, P. LABOYRIE ${ }^{1}$ and C.G. PROSSER ${ }^{2}$ \\ ${ }^{1}$ Dairying Research Corporation Ltd, Private Bag 3123, Hamilton \\ ${ }^{2}$ AgResearch Dairy Science, Private Bag 3123, Hamilton, New Zealand
}

\begin{abstract}
Effects of pasture allowance on the yield, composition and cheese-yielding potential of milk were investigated using 48 Friesian cows in crossover experiments during spring ( $\sim 60$ days after calving) and summer ( $\sim 180$ days after calving). All cows were subjected to two nutritional treatments: ad lib. grazing (pasture allowance $>45$ $\mathrm{kg} \mathrm{DM} / \mathrm{cow} /$ day) and restricted grazing (16-18 kg $\mathrm{DM} /$ cow/day). Milk samples were collected from each cow on the final day of each treatment period and analysed for a range of components. Pasture dry matter intakes (DMI) during treatment periods were determined using the n-alkane technique. Increasing pasture allowance resulted in increased DMI. Cows grazing ad lib. had higher milk yields, concentrations of protein (spring only), casein, whey protein (spring only), casein:whey protein ratio (summer only), $\alpha$-casein, $\beta$-casein and urea, but lower concentrations of serum albumin and immunoglobulin, than cows grazing a restricted pasture allowance. Nutritional effects on milk composition were greatest in spring, at which time theoretical Cheddar cheese yields were greater for milk from cows grazing ad lib. than restricted cows. Concentrations of some milk components were correlated with DMI of cows. These results provide evidence that on-farm management practices can affect milk composition and the potential yield of dairy products. Maintaining an adequate pasture allowance for dairy cows is important not only to maximise milk production, but also to optimise the manufacturing potential of milk.
\end{abstract}

Keywords: casein, cheese, milk, pasture allowance, protein

\section{Introduction}

Milk composition has an important influence on the yield and quality of dairy products (Dalgleish 1992). As the New Zealand dairy industry becomes more aware of this fact, research is focusing on how milk composition can be manipulated on-farm to maximise processability before it reaches the factory. Nutrition is one on-farm influence which can affect milk composition (Murphy \& O’Mara 1993).

The New Zealand dairy industry relies on grazed pasture as almost the sole source of feed. For this reason, any fluctuations in the availability and quality of pasture will alter the cows' plane of nutrition, and therefore, presumably, the volume and composition of milk produced. The study reported here was designed to investigate the effects of pasture allowance on milk composition, and the potential of that milk for cheese manufacture.

\section{Materials and methods}

\section{Animals, treatments and design}

Forty-eight multiparous Friesian cows were subjected to two nutritional treatments in cross-over experiments during spring (October/November; an average of 60 days after calving) and summer (February/March, an average of 180 days after calving). Treatments were $a d$ lib. grazing (pasture allowance $>45 \mathrm{~kg} \mathrm{DM} /$ cow/day) and restricted grazing (pasture allowance 16-18 kg $\mathrm{DM} /$ cow/day). Cows grazed together ad lib. for 10 days before the experiment. The cows were then divided into two groups, one of which was subjected to each nutritional treatment for 8 days. Following this, all cows again grazed together ad lib. for 14 days, and thereafter cows received the alternative treatment for a further 8 days. Cows grazed similar ryegrass-white clover pasture on adjacent paddocks throughout the experiment. Pre-grazing pasture mass was determined using a rising plate meter (L'Huillier \& Thomson 1988) and approximated 4000 and $3300 \mathrm{kgDM} / \mathrm{ha}$ in spring and summer, respectively. Pasture restriction was achieved by reducing the area of pasture available to the cows. Pasture intakes of individual cows were determined using the n-alkane technique (Dove \& Mayes 1991).

\section{Sampling and analyses}

Milk yields were recorded on the final day of each treatment period, and samples of the daily milk were collected from each cow using in-line milk meters (Trutest Ltd., Auckland). Samples were analysed for fat, protein, lactose, somatic cell count (SCC), nitrogen fractions, immunoglobulin $\mathrm{G}$ (Ig G) and bovine serum 
albumin (BSA), using the techniques outlined by Auldist et al. (1998). Proportions of ( $\alpha, \beta$, and $\kappa$-casein were measured using sodium dodecyl sulfate polyacrylamide gel electrophoresis followed by densitometry (Hill 1993).

Theoretical Cheddar cheese yields were calculated using the following formula (Van Slykes theoretical cheese yield formula; Lou \& Ng-Kwai-Hang 1992), assuming a cheese moisture content of $34 \%$ :

Cheddar cheese yield $=((0.93 \times$ fat $\%)+$ $($ casein $\%-0.1))^{*} 1.09 /(1$-cheese moisture\%/100)

\section{Statistical analyses}

Data were analysed in SAS (SAS Version 6; SAS Institute Inc., NC, USA) using the restricted maximum likelihood method of the mixed-model procedure. Analyses were conducted for each season, treating cow and period as random effects and pasture allowance as a fixed effect. Data from cows with SCC exceeding $400000 \mathrm{cells} / \mathrm{ml}$ were omitted from the analyses to avoid the confounding effects of mastitis on milk composition (Auldist \& Hubble 1998).

\section{Results}

Estimated pasture allowances of $>45$ and $16-18 \mathrm{~kg}$ $\mathrm{DM} /$ cow/day resulted in mean DMI of 15.9 and $11.0 \mathrm{~kg}$ $\mathrm{DM} /$ cow/day for $a d l i b$. and restricted cows respectively in spring and 11.0 and $6.6 \mathrm{~kg} \mathrm{DM} / \mathrm{cow} /$ day for ad lib. and restricted cows respectively in summer.

Cows grazing ad lib. had higher milk yields, concentrations of protein (spring only), casein, whey protein (spring only), casein:whey protein ratio (summer only), $\alpha$-casein, $\beta$-casein and urea, but lower concen-trations of BSA and Ig G, than cows grazing a restricted pasture allowance. Concentrations of $\kappa$ casein were greater in milk from ad lib. cows during spring, but greater in restricted cows during summer (Table 1).

In both treatment periods of at least one experiment, pasture DMI was correlated with milk yield and concentrations of protein, casein, $\alpha$-casein, BSA, Ig G and urea (Table 2).

\section{Discussion}

Some previous experiments investigating nutritional effects on milk yield and composition in grazing cows have failed to separate the effects of feed type from the effects of feeding level (Kefford et al. 1995; Mackle et al. 1998). The current experiment had the aim of investigating the effects of pasture availability on milk yield and composition, and so the type of feed (i.e., pasture) was held constant. The observed effects were therefore primarily due to alterations in feeding level, although minor and potentially confounding effects of pasture selection by cows grazing $a d$ lib. are nevertheless acknowledged.

Increasing the pasture allowance was expected to increase pasture intake (Poppi et al. 1987), and this was clearly demonstrated using the n-alkane technique. In turn, the higher DMI increased concentrations of total protein and total casein (Table 1), as was also found by O'Brien et al. (1997). The increased energy intake would have spared amino acids from gluconeogenesis, thus increasing the supply available for milk protein synthesis. Concentrations of the individual caseins similarly increased when pasture allowance was increased, again probably because of a greater supply of amino acids since all caseins are synthesised within the mammary gland. Conversely, concentrations of proteins from the blood (BSA and Ig G), which are less useful for the manufacture of most products, increased in milk during underfeeding. Gray \& Mackenzie (1987) reported similar effects of pasture allowance on serum proteins, which they attributed at least partly to declining milk volumes. It is possible also that increased concentrations of serum proteins in milk during restricted feeding may indicate increased permeability of the mammary epithelia at that time (Stelwagen et al. 1994). Whatever the cause, the results demonstrate that the effects of nutrition can be different for the different milk proteins.

The amount of cheese yielded per kilogram of milk is an important determinant of the profitability of cheesemaking. Cheese-yielding capacity of milk is affected by milk composition; the amount of cheese per $\mathrm{kg}$ milk increases as the concentrations of fat and protein in milk increases (Lou \& Ng-Kwai-Hang 1992). The most important milk protein for manufacturing purposes is casein, particularly but not exclusively for cheese manufacture. It is primarily casein, together with fat, that is incorporated into the curd during cheese-making. For this reason, the Van Slyke formula for predicting cheese yield from milk composition is based around the concentrations of these parameters in the cheesemilk. In the current experiment, theoretical cheese yields in spring were $5 \%$ higher for $a d$ lib. cows than for restricted cows, owing to the higher concentrations of casein. These differences in theoretical Cheddar cheese yield were similar to those for moisture-adjusted Mozzarella cheese yield reported by Guinee et al. (1998), in an experiment in which cheese was actually made from milk from cows grazing different pasture allowances. In summer, level of feeding had no effect on theoretical cheese yields, possibly because the trend for decreased fat concentration in the ad lib. cows offset the increase 
Table 1 Effect of a high and low pasture allowance on milk composition and theoretical cheese yield in spring ( 60 days after calving) and summer ( 180 days after calving).

\begin{tabular}{|c|c|c|c|c|c|c|}
\hline & \multicolumn{3}{|c|}{-------------------- Spring -------------------- } & \multicolumn{3}{|c|}{ - } \\
\hline & Ad lib. & Restricted & SED & Ad lib. & Restricted & SED \\
\hline Pasture allowance & 45 & 18 & - & 50 & 18 & - \\
\hline Milk yield & 20.3 & $15.6^{\star *}$ & 0.48 & 13.4 & 8.4 ** & 0.25 \\
\hline Fat $(\mathrm{g} / \mathrm{kg})$ & 43.8 & 42.6 & 0.64 & 50.2 & 51.4 & 0.85 \\
\hline Protein $(\mathrm{g} / \mathrm{kg})$ & 33.2 & $30.2^{* *}$ & 0.21 & 33.9 & 33.0 & 0.44 \\
\hline Lactose (g/kg) & 49.9 & 49.7 & 0.19 & 49.2 & $48.4^{*}$ & 0.16 \\
\hline Casein $(\mathrm{g} / \mathrm{kg})$ & 27.5 & $25.0^{* *}$ & 0.21 & 27.7 & $26.6^{* *}$ & 0.35 \\
\hline$\alpha$-casein $(\mathrm{g} / \mathrm{kg})$ & 12.7 & $11.3^{* *}$ & 0.23 & 12.9 & $12.2^{\star *}$ & 0.19 \\
\hline$\beta$-casein $(\mathrm{g} / \mathrm{kg})$ & 11.4 & $10.7^{* *}$ & 0.15 & 11.8 & $11.3^{* *}$ & 0.23 \\
\hline$\kappa$-casein $(\mathrm{g} / \mathrm{kg})$ & 2.81 & $2.51^{* *}$ & 0.06 & 2.79 & $2.95^{*}$ & 0.06 \\
\hline Whey $(\mathrm{g} / \mathrm{kg})$ & 5.7 & $5.2^{* *}$ & 0.10 & 6.2 & 6.4 & 0.12 \\
\hline Serum albumin (mg/1) & 208 & $280^{* *}$ & 7.3 & 233 & $387^{* *}$ & 8.9 \\
\hline Immunoglobulin G (mg/1) & 588 & $622^{* *}$ & 11.7 & 558 & $731^{* *}$ & 19.7 \\
\hline Casein:whey protein & 5.0 & 5.0 & 0.13 & 4.6 & $4.2^{* *}$ & 0.07 \\
\hline Urea (mM) & 5.11 & $4.56^{* *}$ & 0.11 & 6.41 & $5.29^{* *}$ & 0.10 \\
\hline Cheese yield $(\mathrm{kg} / 100 \mathrm{~kg} \text { milk })^{\dagger}$ & 11.1 & $10.5^{\star *}$ & 0.11 & 12.1 & 12.1 & 0.18 \\
\hline
\end{tabular}

$\dagger$ Theoretical cheese yield calculated using a modification of Van Slykes theoretical cheese yield formula (Lou \& Ng-Kwai-Hang, 1992).

in casein concentration. These results highlight the importance of maintaining pasture intake, at least during spring, to optimise the yield of casein-derived dairy products such as cheese and caseinate.

The magnitude of the effects of nutrition on milk yield and composition was dependent on time of year, with effects generally being greatest in spring (Table 1 ). This was also reported by Petch et al. (1997) and Mackle et al. (1998). Presumably, this interaction between the effects of season and nutrition was due to other factors which change during the season and which could affect milk yield and composition. Such factors include cow energy requirements, the capacity of the cow to ingest sufficient dry matter to meet requirements, physiological factors associated with stage of lactation, and pasture composition.

Some of the factors noted above were probably responsible for the differences in milk composition between spring and summer (Table 1). Seasonal variation in milk composition has been addressed previously (O'Keeffe 1984; Kefford et al. 1995; Lucey 1996; Auldist et al. 1998) and is not within the scope of this paper. Nevertheless, it is noteworthy that theoretical cheese yields were greater during summer than spring because of the higher casein and fat concentrations. This must be tempered, however, by reduced milk yields and potential product problems associated with low casein:whey ratios at this time (Lucey 1996).

The correlations between DMI and concentrations of milk components in individual cows (Table 2) were consistent with the effects of DMI on mean milk composition outlined above (Table 1). Nevertheless, the variation in the strength and significance of the correlations indicates that DMI was not always a reliable
Table 2 Correlations ${ }^{\dagger}(\times 100)$ between pasture dry matter intake (DMI) and concentrations of milk components in spring and summer.

\begin{tabular}{|c|c|c|c|c|}
\hline & \multicolumn{2}{|c|}{----- Spring ------ } & \multicolumn{2}{|c|}{----- Summer ------ } \\
\hline & Period 1 & Period 2 & Period 3 & Period 4 \\
\hline Milk yield & $58^{*}$ & $60^{*}$ & $78^{*}$ & $81^{*}$ \\
\hline Protein & $61^{*}$ & $44^{*}$ & 22 & 21 \\
\hline Casein & $55^{*}$ & $44^{*}$ & 27 & $30 *$ \\
\hline Whey & $49^{*}$ & 17 & -2 & -13 \\
\hline$\alpha$-casein & $35^{*}$ & $42^{*}$ & 22 & 21 \\
\hline$\kappa$-casein & $42^{*}$ & 21 & -17 & -3 \\
\hline Albumin & $-43^{*}$ & $-55^{\star}$ & $-71^{*}$ & $-66^{*}$ \\
\hline $\lg G$ & -13 & -12 & $-40^{*}$ & $-51^{*}$ \\
\hline Urea & $48^{*}$ & 27 & $39^{*}$ & $69^{*}$ \\
\hline
\end{tabular}

* $\mathrm{P}<0.05$

+ Data presented only for components significantly correlated with DMI in at least one period.

predictor of milk yield, composition or manufacturing potential.

In conclusion, these results provide evidence that on-farm management practices can affect milk composition and hence the potential yield of cheese. A short-term decline in DMI resulting from a reduction in pasture allowance affected concentrations of milk components in different ways, but the extent of these changes was dependent on the time of year. In particular, maintaining an adequate pasture allowance for dairy cows is important not only to maximise milk production, but also to optimise concentrations of casein and therefore the yield of casein-derived products such as cheese. This will be important if manufacturing companies begin to pay for milk based on casein content instead of total protein content. 


\section{ACKNOWLEDGEMENTS}

The authors are grateful to staff of DRC No. 5 Dairy for animal care and sampling; Ms M. Bryant and DRC Milk Composition Laboratory staff for chemical analyses of milk; Mr R. McKee and DRC Nutrition Laboratory staff for alkane analyses; and Ms R. Hooper and Dr H. Henderson for statistical procedures.

\section{REFERENCES}

Auldist, M.J.; Hubble, I.B. 1998. Effects of mastitis on raw milk and dairy products. Australian journal of dairy technology 53: 28-36.

Auldist, M.J.; Walsh, B.J.; Thomson, N.A. 1998. Seasonal and lactational influences on milk composition in New Zealand. Journal of dairy research 65: 401-411.

Dalgleish, D.G. 1992. Bovine milk protein properties and the manufacturing quality of milk. Livestock production science 34: 75-93.

Dove, H.; Mayes, R.W. 1991. The use of plant wax alkanes as marker substances in studies of the nutrition of herbivores: A review. Australian journal of agricultural research 42: 913-952.

Gray, R.M.; Mackenzie, D.D.S. 1987. Effect of plane of nutrition on the concentration and yield of whey proteins in milk. New Zealand journal of dairy science and technology 22: 157-165.

Guinee, T.P.; Mulholland, E.O.; Mullins, C.; Corcoran, C.O.; Connolly, J.F.; Beresford, T.; Mehra, R.; O'Brien, B.J.; Murphy, J.J.; Stakelum, G.; Harrington, D. 1998. Effect of altering daily herbage allowance to cows in mid lactation on the composition, ripening and functionality of low-moisture, part-skim Mozzarella cheese. Journal of dairy research 65: 23-30.

Hill, J.P. 1993. The relationship between $\beta$-lactoglobulin phenotype and milk composition in New Zealand dairy cattle. Journal of dairy science 76 : 281-286.

Kefford, B.; Christian, M.P.; Sutherland, B.J.; Mayes, J.J.; Grainger, C. 1995. Seasonal influences on Cheddar cheese manufacture: influence of diet quality and stage of lactation. Journal of dairy research 62: 529-537.

L'Huillier, P.J.; Thomson, N.A. 1988. Estimation of herbage mass in ryegrass-white clover dairy pastures. Proceedings of the New Zealand Grassland Association 49: 117-122.

Lou, Y.; Ng-Kwai-Hang, K.F. 1992. Effects of fat and protein levels in milk on Cheddar cheese yield. Food research international 25: 437-444.

Lucey, J. 1996. Cheesemaking from grass based seasonal milk and problems associated with late-lactation milk. Journal of the Society of Dairy Technology 49: 59-64.

Mackle, T.R.; Bryant, A.M.; Petch, S.F.; Hill, J.P.; Auldist, M.J. 1998. Nutritional influences on the composition of milk from cows of different protein phenotype in New Zealand. Journal of dairy science 81: $172-180$.

Murphy, J.J.; O'Mara, F. 1993. Nutritional manipulation of milk protein concentration and its impact on the dairy industry. Livestock production science 35: 117-134.

O’Brien, B.; Murphy, J.J.; Connolly, J.F.; Mehra, R.; Guinee, T.P.; Stakelum, G. 1997. Effect of altering the daily herbage allowance in mid lactation on the composition and processing characteristics of bovine milk. Joumal of dairy research 64: 621-626.

O'Keeffe, A.M. 1984. Seasonal and lactational influences on moisture content of Cheddar cheese. Irish journal of food science and technology 8: 39-48.

Petch, S.F.; Bryant, A.M.; Napper, A.R. 1997. Effects of pasture intake and grain supplementation on milk nitrogen fractions. Proceedings of the New Zealand Society of Animal Production 57: 154-156.

Poppi, D.P.; Hughes, T.P.; L'Hullier, P.J. 1987. Intake of pasture by grazing ruminants. pp. 55-64. In: Nicol, A.M. (ed.) Livestock Feeding at Pasture. New Zealand Society of Animal Production Occasional Publication no. 10.

Stelwagen, K.; Davis, S.R.; Farr, V.C.; Eichler, S.J. 1994. Effect of once daily milking and concurrent somatotropin on mammary tight junction permeability and yield of cows. Journal of dairy science 77: 2994-3001. 